NUT OF LAW

DIGITAL REPOSITORY

Faculty Book Display Case

School of Law

$1-1-2002$

\title{
High and Dry: The Texas New Mexico Struggle for the Pecos River
}

\author{
G. Emlen Hall \\ University of New Mexico - School of Law, hall@law.unm.edu
}

Follow this and additional works at: https://digitalrepository.unm.edu/law_facbookdisplay

Part of the Law Commons

\section{Recommended Citation}

Hall, G. Emlen. "High and Dry: The Texas New Mexico Struggle for the Pecos River." (2002): 291 pages.

https://digitalrepository.unm.edu/law_facbookdisplay/3

This Book is brought to you for free and open access by the School of Law at UNM Digital Repository. It has been accepted for inclusion in Faculty Book Display Case by an authorized administrator of UNM Digital

Repository. For more information, please contact amywinter@unm.edu.

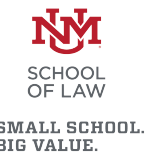




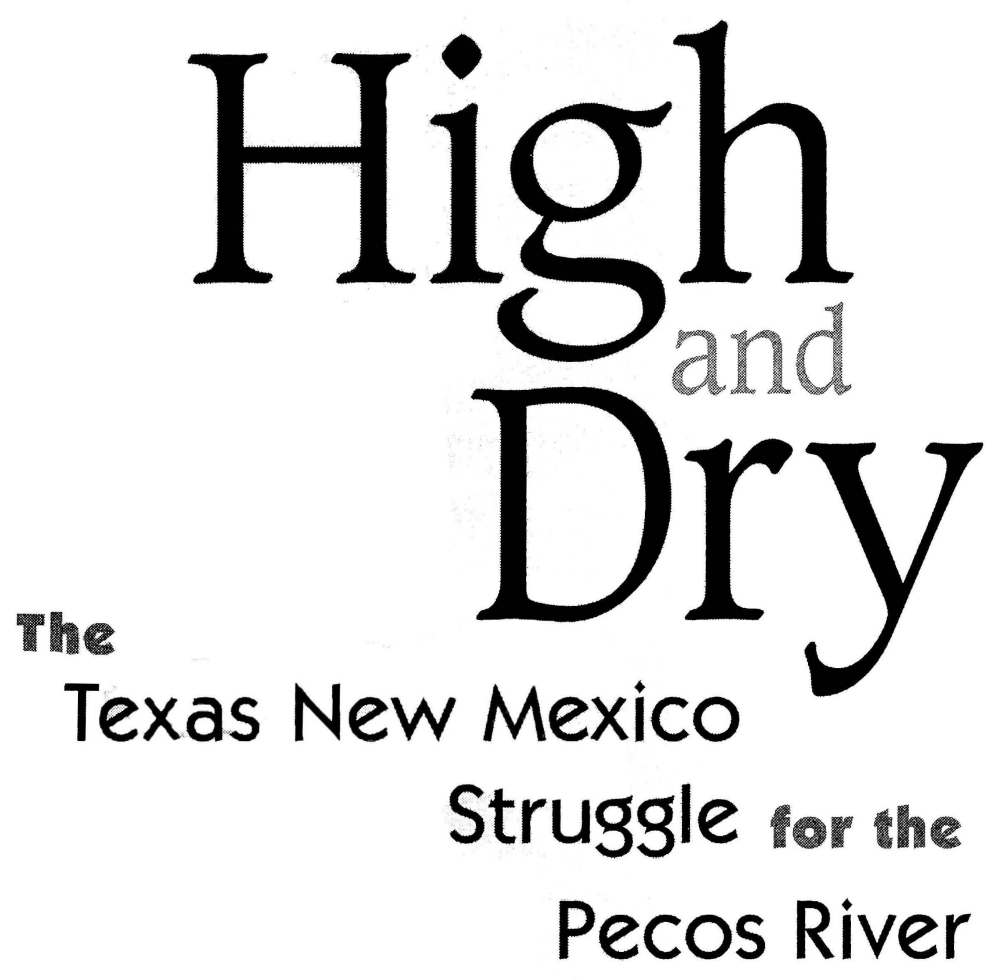

G. Emlen Hall

University of New Mexico Press

Albuquerque. 

(C) 2002 by G. Emlen Hall
First edition
All rights reserved.

Library of Congress Cataloging-in-Publication Data

Hall, G. Emlen, I942-

High and dry : the Texas-New Mexico struggle for the Pecos River / G. Emlen Hall.

p. $\mathrm{cm}$.

Includes index.

ISBN 0-8263-2429-o (cloth)

I. Pecos River (N.M. and Tex.)-Water rights.

2. Texas-Trials, litigation, etc.

3. New Mexico-Trials, litigation, etc.

I. Title.

KF2 576.P43 H35 2002

$346.7304^{\prime} 32-\mathrm{dc} 2 \mathrm{I}$

2001006776 


\section{ACKNOWLEDGMENTS}

Joseph Blecha, Eric Biggs, Beth Hadas, Delaney Hall, Chloe Hall, Gavin Hall, Renea Hicks, David Holtby, Bill Fleming, Jay Groseclose, Morgan Nelson, Ted Occhialino, Bhasker Rau, Steve Reynolds, Leo Romero, D. L. Sanders, John Shomaker, Carl Slingerland, Richard Simms, Karen M. Talley, Charlotte Uram, Sabino Samuel Vigil, Francis West, and Peter White each contributed mightily in different ways to this book. I am indebted to them and the countless others who helped me with this project. 


\section{Contents}

Preface ix

Chapter 1 Flying Court I

Chapter 2 The Tracys' Dream of Carlsbad 24

Chapter 3 Royce J. Tipton Mismeasures

the Pecos 52

Chapter 4 Morgan Nelson's Pecos River World 79

Chapter 5 Leave It to Steve 108

Chapter 6 Jean Breitenstein Tackles the 1947 Condition I30

Chapter 7 The Presumption of

Charles J. Meyers $\quad 164$

Chapter 8 New Mexico Stumbles 197

Chapter 9 The Value of Water, Inch by Inch,

Row by Row 224

Abbreviations $25 \mathrm{I}$

Notes 252

Index 285 


\section{Preface}

Improbable as it sounds, High and Dry is a love story about a lawsuit. As things go, lawsuits are not easy to love and Texas $v$. New Mexico, Supreme Court No. 65 Original, was among the least appealing of them all. For almost twenty years at the end of the twentieth century the U.S. Supreme Court interstate water litigation between two states with a long history of enmity oozed along the Pecos River. The lawsuit was a bottom feeder, sucking up an entire river basin, the institutions built for it, the communities dependent on it and the human lives devoted to it. The lawsuit didn't so much chew up and spit out in pieces the things with which it came into contact as it swallowed them whole, leaving only the outlines of its victims, distended and struggling, in its maw.

In the process, the slow-moving, never-ending lawsuit threatened to transform many of the things that I have come to love in my thirty years as a New Mexican historian and lawyer.

I have loved the Pecos River ever since I pulled over the Glorieta Pass east of Santa Fe in late 1969 and dropped for the first time into the Upper Pecos River Basin. I came from Cambridge, Massachusetts and fell in love with Pecos, New Mexico. For more than ten years, I stayed there. I fished for trout in what is in the Pecos River's upper reaches a high mountain stream. I tried to grow gardens and corn fields, using the ancient irrigation structures of Hispanic and Pueblo Indian Pecos to get the river water to my land. I learned seventeenth-century New Mexican Spanish and its arcane, precise terms for the water I used. It took me ten more years to descend below Santa Rosa where the Pecos River Middle Basin begins and where Texas v. New Mexico really started and another ten years to get to 
Pecos, Texas where the bitter fruits of the Pecos River management that spawned the interstate lawsuit were most directly felt.

By then I already had acquired two passionate biases about the Pecos River. First, I was a New Mexican from Pecos, New Mexico. I'd always seen the river from its top. The way the Rio Grande runs forces New Mexicans into both an upstream and a downstream perspective. The river heads in Colorado and ends in Texas; New Mexico is squeezed inbetween and forced to look in both directions. By contrast, the Pecos River heads in New Mexico and runs down to Texas. New Mexicans only need to look to the state below to figure out their state's interstate rights and obligations. But from the start I had an extreme case of upstream vision, the double disability of someone who learned to see the river from the headwaters of an upstream state.

Astute observers of Texas $v$. New Mexico always attributed a lot to the river perspective of various participants and I think that they are right about me as well. For better or worse, High and Dry is primarily a book about New Mexico's stake in the litigation. Texas had a huge interest in it as well, but I don't see the downstream stakes as clearly, develop them as deeply, or worry over them as paternalistically as I do about New Mexico's.

I was also devoted to New Mexico State Engineer Steve Reynolds. As a journalist, I was introduced to Reynolds in the early I970s and, as a lawyer, I made his acquaintance, starting in the mid-I970s. Shortly thereafter, I joined his legal staff at the State Engineer Office and stayed until the mid I980s. As you will learn from the story to come, I worked off and on for Reynolds on Texas $v$. New Mexico in that period, mostly in the fog of endless, ambiguous battles over laws that didn't quite work and engineering that didn't quite add up. However, the work delighted me because it was so close to New Mexico and its history, a hydroscape that endlessly fascinated me the more I learned about it. And the closer that I got to the history, the closer I got to Steve Reynolds.

Already a legend in his time when I came to know him, Reynolds was a brooding omnipresence where we all worked in the Bataan Memorial Building near the Plaza in Santa Fe. Reynolds was there when we came in to work in the morning and was still there when most of us left in the early evening. During the week, he stuck to his own beautiful corner office and ventured out from time to time, to take care of business. But on Saturday mornings, when the rest of New Mexico state government formally was shut down, Reynolds usually would show up at the office, dressed casually and ready to work. Somehow he let it be known that his lawyers were supposed to show up too. I often did.

On those pared down Saturday mornings I'd work and wait for 
Reynolds to come around, gathering up the small scattering of lawyers where we all worked and marching us off to the nearby Forge Restaurant for coffee and chat. A relaxed and available Reynolds would regale us with all manner of water war stories, some set in New Mexico, some in other western states, some in Washington, D.C. where he spent a lot of time and had a lot of contacts. The stories were all funny and usually directed to the follies of other western natural resource managers. We heard tales of a New Mexico Fish and Game head who was a "helluva lion hunter," in Reynolds' words, and not much more and a California state engineer who insisted on inserting language into the original I968 Wilderness Act that was so convoluted that no one understood what the statute meant. But somehow Reynolds convinced us over many Saturday mornings like this that there was a point to all of these stories.

Over and over again, Steve Reynolds has been described as a man of singular principle. Most people took this to mean that he was a state bureaucrat who didn't curry favor and didn't take bribes. He did and he didn't, but that was beside the point. He was a man of principle because he was so sure of what the first principle of New Mexico's water policy should be: the scientific management of limited water to achieve the most economically efficient beneficial use of the state's scant supplies. Texas v. New Mexico swallowed Reynolds and his principle whole and disgorged them at the suit's end distended, swollen, and broken.

By then Reynolds's first principle was vying with a whole new range of competing first principles: water for Texas, water for federally protected aquatic endangered species, water for the Pecos River itself, water for all manner of other uses. Alone, first principles are elegant; together, they compete like alligators in a swamp for survival. By definition, there can only be one winner among competing first principles but it takes a long time and is certainly a mess making that determination. No winner has emerged in the aftermath of Texas $v$. New Mexico.

In the process a lot of things died. Scientific management of the river died, replaced by a much more complex political balancing of incompatible factors. The Pecos River itself threatened to die, so pushed and pulled between demands on it that it could hardly respond to any of them. Steve Reynolds died and took with him to the grave his singleminded devotion to his own first principle.

He left a lot behind, including my respect for him and his curiosity about my stumbling efforts to write. For awhile in the late I970s I wrote a column for the Santa Fe Reporter. To my surprise Reynolds read them. In one of the first I wrote about the death of an old Pecos Hispanic, calling the article "a threnody." Reynolds sent me a hand-written note, 
praising the story and thanking me for alerting him to a word he hadn't known until then.

In July I983 I made a big move that had a very small impact on Texas v. New Mexico. Giving up the full-time practice of law, I joined the faculty at the University of New Mexico School of Law. I wrote Reynolds a short note telling him of my plans. In that deeply courteous manner of his, he immediately wrote back. "You have contributed much to the effective operation of the State Engineer Office," he began,

and I have found our association both personally and professionally gratifying. I have admired and enjoyed your writing style even when you were holding me up to the opprobrium and scorn of our fellowman or giving up a million acres of New Mexico irrigation. Your contribution to the "Milagro Beanfield War" played an important part in bringing me the award of which I am most proud-A T-shirt emblazoned with "Viva Milagro Beanfield." That award was given to me by the Central Clearing House as an "earth enemy" for the part I played in killing legislation to establish a State NEPA law. I wish you every possible success in your new undertaking. The Lord knows we need some good water lawyers; it could not be in the public interest for the State Engineer to win all cases on appeal.

With that peculiarly New Mexican combination of affection, teasing and self-deprecation, Steve Reynolds let me go, back to the university world where he had begun before he became state engineer. I kept writing and High and Dry is the result.

I didn't write the book as a threnody to Reynolds. I did write High and Dry to pay homage to the institutions that made the river what it was in the twentieth century: the people, the communities, the state bureaucrats, the federal compacts and the Supreme Court lawsuits. The 2 Ist century will remake the river in its own image even if the humans, who have struggled to force the river to behave for centuries, recede and the river itself reemerges. I have no doubt that in another hundred years the Pecos River that I describe here will be unrecognizable. But I can't see far enough into the future to know what forms that transformation will take. It will take another century to reshape it.

I pray that the Pecos River survives but, as its name implies, High and Dry hardly shows the way to survival. In the meantime, I leave you with High and Dry and the forces that made the river what it was in the twentieth century and me who I am towards the end of my working life. I grew up with Steve Reynolds and the Pecos River and now I'm looking back, seeing where we came from, how we got here and who we are. 